\section{Treating 'Primofiori' Lemons in Cold Storage with Intermittent Warming and Carbon Dioxide}

\author{
Francisco Artés', Angel J. Escriche, and Jose G. Marin \\ Postharvest and Refrigeration Laboratory, Centro de Edafologia y Biología \\ Aplicada del Segura, Consejo Superior de Investigaciones Cientifícas, P.O. \\ Box 4195, Murcia, Spain \\ Additional index words. Citrus limon, temperature, red blotch, peteca, membranosis, rind \\ pitting, oleocellosis, chilling injury, Alternaria citri
}

Abstract. Several intermittent 13C warming treatments were applied to 'Primofiori' lemons (Citrus limon Burn) stored at 2 or SC. Fruit stored at $13 \mathrm{C}$ were treated with $10 \%$, 2090, or $30 \% \mathrm{CO}_{2}$ for 24 hours at weekly intervals. Reduction in decay and physiological disorders was best with two cycles of 2 weeks at $2 \mathrm{C}$ and 2 weeks at $13 \mathrm{C}$ and relative humidity $>95 \%$. Under this storage condition, soluble solids concentration, $\mathrm{pH}$, titratable acidity, and reducing sugars did not change relative to values at harvest, but the concentration of ascorbic acid increased and that of nonreducing sugars decreased in relation to harvest values. Carbon dioxide treatments did not prevent the development of alternaria (Alternaria citri Ell. \& Pierce) rot and red blotch disorder, but effectively prevented the development of membranosis, rind pitting, and oleocellosis.

Several techniques have been applied to alleviate chilling injury (CI) in lemons stored for 2 to 6 months in relative humidities (RHs) $>90 \%$. These techniques include using moderate temperatures $(\approx 13 \mathrm{C})$, controlled-atmosphere storage, intermittent fruit warming during cold storage, applying 2-(4-thiazolil-benzimidazole) (thiabendazole) and methyl $\{1-$ [(butylamino)carbonyl]-1H-benzimidazol-2yl ]carbamate (benomyl), prestorage curing at higher temperatures, $\mathrm{CO}_{2}$ treatments, and us-

Received for publication 5 Aug. 1992. Accepted for publication $11 \mathrm{Feb} .1993$. The cost of publishing this paper was defrayed in part by the payment of page charges. Under postal regulations, this paper therefore must be hereby marked advertisement solely to indicate this fact.

'To whom reprint requests should be addressed. ing semipermeable plastic films.

Storing 'Verna', 'Primofiori', 'Fino', 'Euusually induces physiological disorders (Artés and Carpena, 1977; Artés et al., 1979, 1981; Chalutz et al., 1981; Cohen et al., 1983; Guillén et al., 1980). The main disorders are red blotch or adustiosis, peteca, membranosis or membranous stain, oleocellosis, and rind pitting or deep brown spot (Artés and Escriche, 1988; Artés et al., 1981). Disorder severity is related to cultivar, environmental conditions at picking, fruit maturity, and postharvest treatments (temperature, $\mathrm{RH}$, ventilation, packinghouse treatments, and storage duration).

Inconsistent results have been reported on the effectiveness of controlled-atmosphere storage in reducing CI (Wang, 1982). 'Primofiori' lemons exposed to $12 \% \mathrm{O}_{2}$ and reka', and 'Villa-Franka' lemons at 12 to $14 \mathrm{C}$
$<2 \% \mathrm{CO}_{2}$ at $13 \mathrm{C}$ and $\mathrm{RH}>95 \%$ gave the best control of physiological disorders during 2 months of storage (Artès et al., 1981; Guillén et al., 1980).

Davis and Hoffmann (1973) suggested intermittent warming to reduce citrus fruit CI. Intermittently warming 'Villa-Franka' lemons for 7 days at $13 \mathrm{C}$ every 21 days during storage at 2 or $8 \mathrm{C}$ eliminated membranosis, prevented rind pitting, and reduced decay compared with storing lemons continuously at 2 or 8C for 6 months (Cohen et al., 1983). Good results also were obtained in commercial practice (Cohen, 1988; Cohen et rd., 1990). Intermittent warming for 7 days at $13 \mathrm{C}$ after 21 days at $2 \mathrm{C}$ prevented disorders in 'Fine' lemons (Artés et al., 1990),

Paraffin at 25 or $50 \mathrm{~g} \cdot$ liter $^{-1}$ and benomyl at $0.2 \mathrm{~g} \cdot \mathrm{liter}^{-1}$ or thiabendazole at $4 \mathrm{~g} \cdot \mathrm{liter}^{-1}$ or 3(3,5-dichlorophenyl)-N-(1-methylethyl)2,4(1H,3H)-pyrimidinedione(iprodione)at 0.2 $\mathrm{g} \cdot$ liter $^{-1}$ reduced red blotch disorder but not membranosis in 'Primofiori' lemons stored at 13C and 90\% RH for 2 months (Artés et rd., 1983).

Conditioning lemons for 1 week at $15 \mathrm{C}$ before storing them at $\mathrm{IC}$ significantly reduced CI incidence and severity (Houck et al., 1990). Prestorage treatments with high $\mathrm{CO}_{2}$ concentrations $(10 \%, 20 \%$, or $40 \%)$ for 3 or 7 days at $21 \mathrm{C}$ significantly reduced rind pitting in grapefruit stored at $4.4 \mathrm{C}$ for 8 or 12 weeks (Hatton et al., 1975). Seal-packaging individual fruit in high-density polyethylene plastic film prevented or reduced $\mathrm{CI}$ in lemon (Ben-Yehoshua et al., 197\% Cohen et al., 1990).

Our study reports the effect of constant temperature storage, intermittent warming, and intermittent $\mathrm{CO}_{2}$ treatments on 'Primofiori' lemon storage behavior. Correlations between fruit susceptibility to decay and CI and physicochemical characteristics and storage conditions also were investigated.

'Primofiori' lemons were harvested from a 20-year-old orchard on 17 Jan. 1988 in Crevillente (Alicante); Spain, and transported by car the same day to our laboratory in Murcia, 
Table 1. Lemon juice composition at harvest and after 8 weeks of storage under various conditions.

\begin{tabular}{|c|c|c|c|c|c|c|c|}
\hline \multirow[b]{2}{*}{ Treatment $^{\mathrm{y}}$} & \multicolumn{7}{|c|}{ Chemical constituents } \\
\hline & $\begin{array}{l}\text { Extractable } \\
\text { juice }^{x}\end{array}$ & $\begin{array}{c}\text { SSC }^{z} \\
(\% \text { juice })\end{array}$ & $\mathrm{pH}$ & $\begin{array}{c}\text { Acidity } \\
\text { (\% juice) }\end{array}$ & $\begin{array}{c}\text { Ascorbic } \\
\text { acid } \\
\text { (mg/100 ml juice) }\end{array}$ & $\begin{array}{l}\text { Reducing } \\
\text { sugars } \\
\text { (\% juice) }\end{array}$ & $\begin{array}{l}\text { Nonreducing } \\
\text { sugars } \\
\text { (\% juice) }\end{array}$ \\
\hline$A(2 C)$ & $45.3 \mathrm{c}$ & $8.6 \mathrm{c}$ & $2.3 \mathrm{~b}$ & $6.6 \mathrm{de}$ & $49.2 \mathrm{a}-\mathrm{c}$ & $1.2 \mathrm{e}$ & $0.8 \mathrm{e}$ \\
\hline $\mathrm{B}(8 \mathrm{C})$ & $49.2 \mathrm{ab}$ & $8.9 a-c$ & $2.4 \mathrm{ab}$ & $6.2 \mathrm{~g}$ & $49.5 \mathrm{a}-\mathrm{c}$ & $1.5 \mathrm{de}$ & $0.9 \mathrm{~d}$ \\
\hline$C(13 C)$ & $49.5 \mathrm{a}$ & $9.2 a-c$ & $2.3 \mathrm{~b}$ & $6.3 \mathrm{fg}$ & $49.0 \mathrm{a}-\mathrm{c}$ & $1.5 \mathrm{de}$ & $1.0 \mathrm{~d}$ \\
\hline $\mathrm{E}$ & $46.3 \mathrm{bc}$ & $9.3 \mathrm{ab}$ & $2.3 \mathrm{~b}$ & $7.0 \mathrm{ab}$ & $50.1 \mathrm{a}-\mathrm{c}$ & $1.7 \mathrm{~cd}$ & $1.0 \mathrm{~d}$ \\
\hline $\mathrm{F}$ & $49.9 \mathrm{a}$ & $9.4 \mathrm{a}$ & $2.4 \mathrm{ab}$ & $6.7 \mathrm{c}-\mathrm{e}$ & $52.4 \mathrm{a}$ & $1.5 \mathrm{de}$ & $0.9 \mathrm{~d}$ \\
\hline G & $47.6 a-c$ & $8.6 \mathrm{c}$ & $2.5 \mathrm{a}$ & 6.5 ef & $50.1 \mathrm{abc}$ & $1.4 \mathrm{de}$ & $1.0 \mathrm{~d}$ \\
\hline $\mathbf{H}$ & $46.4 \mathrm{bc}$ & $9.2 \mathrm{a}-\mathrm{c}$ & $2.4 \mathrm{ab}$ & $7.1 \mathrm{a}$ & $49.5 \mathrm{a}-\mathrm{c}$ & $1.7 \mathrm{~cd}$ & $1.1 \mathrm{c}$ \\
\hline \multicolumn{8}{|c|}{$\mathrm{CO}_{2}$ for $24 \mathrm{~h} /$ week at $13 \mathrm{C}$} \\
\hline I (10\%) & $47.6 \mathrm{a}-\mathrm{c}$ & $9.0 \mathrm{a}-\mathrm{c}$ & $2.3 \mathrm{~b}$ & $6.8 \mathrm{~b}-\mathrm{d}$ & $51.3 \mathrm{ab}$ & $3.4 \mathrm{a}$ & $1.4 \mathrm{a}$ \\
\hline $\mathrm{J}(20 \%)$ & $48.9 \mathrm{ab}$ & $8.9 \mathrm{a}-\mathrm{c}$ & $2.4 \mathrm{ab}$ & $6.6 \mathrm{de}$ & $47.9 \mathrm{a}-\mathrm{c}$ & $2.3 \mathrm{~b}$ & $1.2 \mathrm{~b}$ \\
\hline
\end{tabular}

${ }^{2} \mathrm{SSC}=$ soluble solids concentration.

${ }^{y} \mathrm{D}=2$ cycles, 1 week $2 \mathrm{C}, 3$ weeks $13 \mathrm{C}, \mathrm{E}=2$ cycles, 1 week $8 \mathrm{C}, 3$ weeks $13 \mathrm{C} ; \mathrm{F}=2$ cycles, 2 weeks $2 \mathrm{C}, 2$ weeks $13 \mathrm{C} ; \mathrm{G}=2$ cycles, 3 weeks $2 \mathrm{C}, 1$ week $13 \mathrm{C}$;

$\mathrm{H}=2$ cycles, 3 weeks $8 \mathrm{C}, 1$ week $13 \mathrm{C}$.

${ }^{x}$ Percentage $(w / w)$ of juice to fresh weight.

"Mean separation in columns by Duncan's multiple range test, $P \leq 0.05$.

Spain (40 km from Crevillente), where they were kept at 13C. The next day, the fruit were washed with water and dipped in thiabendazole at $2 \mathrm{~g} \cdot \mathrm{liter}^{-1}$ at $20 \mathrm{C}$ for $3 \mathrm{~min}$. Fruit of uniform size and appearance $(120 \mathrm{~g}, 60 \mathrm{~mm}$ in diameter, green-yellow, and free of defects) were randomized into 150 -fruit lots as three replicates of 50 fruit each per treatment. The plastic boxes containing the fruit were placed inside 360 -liter gas-tight chambers in cold storage rooms at 2,8 , or $13 \mathrm{C}$ with an $\mathrm{RH}>95 \%$ in each. The respective vapor pressure differences were $\leq 30,60$, and $80 \mathrm{~Pa}$.

The treatments were A) 8 weeks at 2C, B) 8 weeks at $8 \mathrm{C}, \mathrm{C}) 8$ weeks at $13 \mathrm{C}, \mathrm{D}) 1$ week at $2 \mathrm{C}+3$ weeks at $13 \mathrm{C}+1$ week at $2 \mathrm{C}+3$ weeks at $13 \mathrm{C}$, E) 1 week at $8 \mathrm{C}+3$ weeks at $13 \mathrm{C}+1$ week at $8 \mathrm{C}+3$ weeks at $13 \mathrm{C}, \mathrm{F}) 2$ weeks at $2 \mathrm{C}+2$ weeks at $13 \mathrm{C}+2$ weeks at $2 \mathrm{C}$ +2 weeks at $13 \mathrm{C}, \mathrm{G}) 3$ weeks at $2 \mathrm{C}+1$ week at $13 \mathrm{C}+3$ weeks at $2 \mathrm{C}+1$ week at $13 \mathrm{C}, \mathrm{H}) 3$ weeks at $8 \mathrm{C}+1$ week at $13 \mathrm{C}+3$ weeks at $8 \mathrm{C}$ +1 week at $13 \mathrm{C}, \mathrm{I}) 10 \% \mathrm{CO}_{2}$ for $24 \mathrm{~h}$ weekly during storage at $13 \mathrm{C}, \mathrm{J}) 20 \% \mathrm{CO}_{2}$ for $24 \mathrm{~h}$ weekly during storage at $13 \mathrm{C}$, and $\mathrm{K}) 30 \%$ $\mathrm{CO}_{2}$ for $24 \mathrm{~h}$ weekly during storage at $13 \mathrm{C}$.

Physical and chemical analyses were performed on three lo-fruit samples at harvest and after each storage trial. Fruit were weighed with a precision of $\pm 0.01 \mathrm{~g}$ and weight loss was calculated as the percentage of initial fresh weight. Extractable juice obtained by squeezing was calculated as the percentage $(w / w)$ of juice to fresh weight. Juice was used to determine total soluble solids concentration (SSC), $\mathrm{pH}$, titratable acidity (TA), reducing and nonreducing sugars, and ascorbic acid. SSC was determined with an Abbé refractometer (readings at 20C). TA, calculated as the percentage of citric acid, was determined by titrating $1 \mathrm{ml}$ of juice with $0.1 \mathrm{~N} \mathrm{NaOH}$. Reducing and nonreducing sugars were determined using the method of Ting (1956). Ascorbic acid was determined by the Association of Official Analytical Chemists (AOAC, 1984) calorimetric method.

Carbon dioxide concentrations were obtained using calibrated capillaries, differential manometers, and gas mixers enriched with a known flow of compressed air. The gas flow was humidified in a mixer before entering the gas-tight chambers containing the fruit.

After they were removed from storage, all fruit were examined for decay and disorders.

Data were subjected to analysis of variance and means were separated by Duncan's multiple range test, where appropriate.

Juice composition of lemons stored for 8 weeks at $2 \mathrm{C}$ did not show any significant difference in constituents, except for a slightly lower nonreducing sugar content compared to fruit at harvest (Table 1). TA and nonreducing sugars decreased in lemons stored at 8 or $13 \mathrm{C}$ compared to fruit at harvest. No significant differences were evident between the latter two temperatures. Chemical composition of juice from lemons under intermittent warming was not different or only slightly different from fruit at harvest. Carbon dioxide promoted higher levels of reducing sugars, but nonreducing sugars were higher only in lemons treated with $10 \%$ and $20 \% \mathrm{CO}_{2}$ relative to

Table 2. Incidence of weight loss, decay, and physiological disorders of lemons after 8 weeks of storage under various conditions.

\begin{tabular}{|c|c|c|c|c|c|c|c|}
\hline \multirow[b]{2}{*}{ Treatment' } & \multirow[b]{2}{*}{$\begin{array}{c}\text { Wt } \\
\text { loss }(\%)\end{array}$} & \multicolumn{6}{|c|}{ Decay and disorders (\% fruit affected) } \\
\hline & & Alternaria & $\begin{array}{c}\text { Red } \\
\text { blotch }\end{array}$ & Peteca & Membranosis & Pitting & Oleocellosis \\
\hline \multicolumn{8}{|c|}{ Cold storage } \\
\hline B (8C) & $3.4 \mathrm{ab}$ & $0 \mathrm{c}$ & $9.3 \mathrm{c}$ & $0 \mathrm{~b}$ & $19.3 \mathrm{a}$ & $0.7 \mathrm{~b}$ & $0.7 \mathrm{~b}$ \\
\hline $\mathrm{C}(13 \mathrm{C})$ & $4.8 \mathrm{a}$ & $3.3 \mathrm{a}$ & $44.0 \mathrm{~b}$ & $07 \mathrm{~b}$ & $1.3 \mathrm{e}$ & $0 \mathrm{~b}$ & $0 \mathrm{~b}$ \\
\hline \multicolumn{8}{|c|}{ Intermittent warming } \\
\hline $\mathrm{D}$ & $3.1 \mathrm{ab}$ & $2.0 \mathrm{ab}$ & $35.3 \mathrm{~b}$ & $0 \mathrm{~b}$ & $12.7 \mathrm{de}$ & $2.7 \mathrm{~b}$ & $4.0 \mathrm{~b}$ \\
\hline G & $1.4 \mathrm{~b}$ & $0 \mathrm{c}$ & $0 \mathrm{~d}$ & $4.0 \mathrm{a}$ & $52.6 \mathrm{~b}$ & $0.7 \mathrm{~b}$ & $3.3 \mathrm{~b}$ \\
\hline $\mathrm{H}$ & $1.6 \mathrm{~b}$ & $0 \mathrm{c}$ & $9.3 \mathrm{c}$ & $1.3 \mathrm{~b}$ & $81.0 \mathrm{a}$ & $2.7 \mathrm{~b}$ & $4.0 \mathrm{~b}$ \\
\hline \multicolumn{8}{|l|}{$\mathrm{CO}_{2}$ at $13 \mathrm{C}$} \\
\hline I $(10 \%)$ & $3.1 \mathrm{ab}$ & $2.7 \mathrm{a}$ & $70.1 \mathrm{a}$ & $0 \mathrm{~b}$ & $0 \mathrm{e}$ & $0 \mathrm{~b}$ & $0 \mathrm{~b}$ \\
\hline $\mathrm{J}(20 \%)$ & $1.6 \mathrm{~b}$ & $2.7 \mathrm{a}$ & $73.3 \mathrm{a}$ & $0 \mathrm{~b}$ & $0 \mathrm{e}$ & $0 \mathrm{~b}$ & $0 \mathrm{~b}$ \\
\hline K $(30 \%)$ & $3.3 \mathrm{ab}$ & $1.3 \mathrm{a}-\mathrm{c}$ & $84.0 \mathrm{a}$ & $0 \mathrm{~b}$ & $0 \mathrm{e}$ & $0 \mathrm{~b}$ & $0 \mathrm{~b}$ \\
\hline
\end{tabular}

${ }^{2} \mathrm{D}=2$ cycles, 1 week $2 \mathrm{C}, 3$ weeks $13 \mathrm{C}$; $\mathrm{E}=2$ cycles, 1 week $8 \mathrm{C}, 3$ weeks $13 \mathrm{C} ; \mathrm{F}=2$ cycles, 2 weeks $2 \mathrm{C}, 2$ weeks $13 \mathrm{C} ; \mathrm{G}=2$ cycles, 3 weeks $2 \mathrm{C}, 1$ week $13 \mathrm{C}$; $\mathrm{H}=2$ cycles, 3 weeks $8 \mathrm{C}, 1$ week $13 \mathrm{C}$.

'Mean separation in columns by Duncan's multiple range test, $P \leq 0.05$. 
fruit at harvest or to most storage treatments (Table 1).

Compared to its value at harvest, ascorbic acid concentration was higher with 2 weeks at $2 \mathrm{C}+2$ weeks at $13 \mathrm{C}$ and $10 \% \mathrm{CO}_{2}$ (Table 1 ).

Continuous storage at $2 \mathrm{C}$ and intermittent warming of two cycles of 2 weeks at $2 \mathrm{C}+2$ weeks at $13 \mathrm{C}$ and two cycles of 3 weeks at $2 \mathrm{C}$ +1 week at $13 \mathrm{C}$ were best for retaining original color (data not shown). Few differences in weight loss were evident among the treatments after removing fruit from storage (Table 2).

Thiabendazole was effective in controlling fungal diseases, and incidence of alternaria rot was low $(<3 \%)$ for all treatments (Table 2$)$. Red blotch, however, was extensive in most treatments, except for storage at $2 \mathrm{C}$ and intermittent warming 3 weeks at $2 \mathrm{C}+1$ week at 13C. Incidence was high in treatments $\mathrm{C}-\mathrm{E}$ and in $\mathrm{CO}_{2}$-treated fruits. Peteca, like alternaria rot, also was quite low in the stored fruit.

High $\mathrm{CO}_{2}$ prevented membranosis, oleocellosis, and rind pitting (Table 2). Continuous storage at $13 \mathrm{C}$ was better than any other non$\mathrm{CO}_{2}$ treatment for reducing membranosis. The worst storage conditions for membranosis were 3 weeks at $8 \mathrm{C}+1$ week at $13 \mathrm{C}$ and continuous storage at $8 \mathrm{C}$. Although this disorder occurred on many fruit, its intensity was slight. The incidence of rind pitting and oleocellosis was low $(<4 \%)$, except for lemons stored continuously at $2 \mathrm{C}$.

'Primofiori' (Artés et al., 1981; Guillén et al., 1980) and 'Villa-Franka' (Cohen et al., 1983) lemons are sensitive to low temperatures. There is a close correlation between disorder development and storage conditions. In lemons stored continuously at 2,8 , or $13 \mathrm{C}$, incidence of peteca, membranosis, rind pitting, and oleocellosis was higher at the lower storage temperatures (Artés and Escriche, 1988; Artés et al., 1981, 1990; Chalutz et al., 1981; Cohen et al., 1983, 1990). The best temperature for continuous cold storage in air for 'Primofiori' was $13 \mathrm{C}$, which eliminated the development of peteca, membranosis, pitting, and oleocellosis. Similar results were found by Cohen et al. (1983) with 'Villa-Franka' using the same temperatures. In our study, red blotch was more severe at the higher storage temperature, and intermittent warming reduced its incidence. According to our previous observations (Artés and Escriche, 1988), 'Primofiori' lemons were more sensitive to red blotch and membranosis than to peteca, rind pitting, and oleocellosis (Table 2).

The incidence of decay and rind pitting with intermittent warming regimes of two cycles of 3 weeks at $2 \mathrm{C}+1$ week at $13 \mathrm{C}$ and two cycles of 3 weeks at $8 \mathrm{C}+1$ week at $13 \mathrm{C}$ in our study agreed with the results obtained by Cohen et al. (1983) with 'Villa-Franka' using the same treatments. However, membranosis was not eliminated in our study, and weight loss was higher in their experiments than in ours after 2 months of cold storage.

The effectiveness of intermittent $\mathrm{CO}_{2}$ treatments during cold storage to reduce some types of disorders (particularly membranosis, oleocellosis, and rind pitting) has not been reported previously for lemons.

Juice content and composition were similar to that reported by us (Artés et al., 1981; Guillén et al., 1980) in the same variety, and by Cohen $(1983,1988,1990)$ in 'Villa-Franka' lemons given similar treatments. The slight increase in ascorbic acid concentration we noted also was reported by E1-Nabawy et al. (1977) with 'Eureka' lemons stored continuously in air at $14 \mathrm{C}$ for 2 months. The reason for this behavior is unknown. Possibly, the biosynthetic route continues its action under these storage conditions.

This study showed that best quality retention in stored 'Primofiori' lemons was obtained with intermittent warming cycles of 2 weeks at $2 \mathrm{C}+2$ weeks at $13 \mathrm{C}$ and $\mathrm{RH}>95 \%$. This regime, not previously reported for lemon, prevented the development of alternaria rot, peteca, oleocellosis, and rind pitting and reduced the incidence of red blotch. However, membranosis was not effectively controlled. Under this storage condition, SSC, $\mathrm{pH}, \mathrm{TA}$, and reducing sugars did not change relative to values at harvest, but ascorbic acid concentration increased.

\section{Literature Cited}

Artés, F. and O. Carpena. 1977. Controlled atmosphere storage of 'Primofiori' lemon. Proc. Intl. Soc. Citricult. 3:1137-1142.

Artés, F. and A. Escriche. 1988. Maladies physiologiques des agrumes et nouvelles techniques de réfrigération. Rev. Gen. Froid 12:47-51.

Artés, F., A. Escriche, and J.G. Marín. 1990. Application of intermittent temperature treatments and carbon dioxide shocks for storage of 'Fino' lemon, p. 3356-3361. In: P. Zeuthen, J.C. Cheftel, C. Eriksson, T.R. Gonnley, P. Linko, and K. Paulus (eds.). Processing and quality of foods. Elsevier Applied Science, London.

Artés, F., M.C. Guillén, and A. Escriche. 1981. Physiological disorders in the storage of lemon fruits. Proc. Intl. Soc. Citricult. 2:768-772.

Artés,F., M.C. Guillén, G. Guzmán, andJ.G. Marín.
1979. Conservation des citrons Verna en atmosphère contròlée. XVth Intl. Congr. Refrigeration 3:6678.

Artès, F., J.J. Sánchez, A. Escriche, and J.G. Marín. 1983. Influence de divers traitements paraffiniques et fungicides sur la conservation frigorifique de citrons. XVIth Intl. Congr. Refrigeration 3:363-369.

Association of Official Analytical Chemists. 1984. Official methods of analysis. 15th ed. Assn. Offic. Anal. Chemists, Washington, D.C.

Ben-Yehoshua, S., I. Kobiler, and B. Shapiro. 1979. Some physiological effects of delaying deterioration of citrus fruits by individual seal packaging in high density polyethylene film. J. Amer. Soc. Hort. Sci. 104:868-872.

Chalutz, E., J. Waks, and M. Schiffmann-Nadel. 1981. The different responses of several citrus fruits cultivars to low temperatures. Proc. Intl. Soc. Citricult. 2:773-774.

Cohen, E. 1988. Commercial use of long-term storage of lemon with intermittent warming. HortScience 23:400.

Cohen, E., S. Ben-Yehoshua, I. Rosemberger, Y. Shalom, and B. Shapiro. 1990. Quality of lemons sealed in high density polyethylene film during long-term storage at different temperatures with intermittent warming. J. Hort. Sci. 65:603-610.

Cohen, E., M. Shuali, and Y. Shalom. 1983. Effect of intermittent warming on the reduction of chilling injury of 'Villa Franka' lemon fruits stored at cold temperature. J. Hort. Sci. 58:593598.

Davis, P.L. and R.C. Hoffmann. 1973. Reductions of chilling injury of citrus fruits in cold storage by intermittent warming. Food Sci. 38:871-873.

El-Nabawy, S. M., M.M. El-Hammady, A.A. ElHammady, and A. E1-Gazzawy. 1977. Effects of postharvest applications of 2,4-D, GA and waxing on the keeping quality of lemons in cold storage. Proc. Intl. Soc. Citricult. 3:1135-1 137.

Guillén, M. C., F. Artés, and J.G. Marín. 1980. Conservación del limón 'Primofiori' o 'Fine' en atmósfera normal y controlada. Proc. 3rd Congr. National Química, Spain 2:319-327.

Hatton, T.T., R.H. Cubbedge, and W. Grierson. 1975. Effects of prestorage carbon dioxide treatments and delayed storage on chilling injury of 'Marsh' grapefruit. Proc. Fla. State Hort. Soc. 88:335-338.

Houck, L. G., J.F. Jenner, and B.E. Mackey. 1990. Seasonal variability of the response of desert lemons to rind injury and decay caused by quarantine cold treatments. J. Hort. Sci. 65:611-617.

Ting, S.V. 1956. Rapid calorimetric methods for simultaneous determination of total reducing sugars and fructose in citrus juices. J. Agr. Food Chem. 4:263-266.

Wang, C.Y. 1982. Physiological and biochemical responses of plants to chilling stress. HortScience 17:173-186. 